\title{
The Knowledge of Awareness on Designing Physical Learning Environment for Autism
}

\author{
Roslinda Ghazali ${ }^{1}$, Siti Rasidah Md Sakip ${ }^{2}$, Ismail Samsuddin ${ }^{3}$, Heba Samra ${ }^{4}$ \\ ${ }^{1}$ Department of Post-graduate, Faculty of Architecture, Planning \& Surveying, Universiti Teknologi MARA Perak Branch, Seri Iskandar \\ Campus, 32610, Perak, Malaysia. \\ ${ }^{2}$ Department of Landscape Architecture, Faculty of Architecture, Planning \& Surveying, Universiti Teknologi MARA Perak Branch, Seri \\ Iskandar Campus, 32610, Perak, Malaysia \\ ${ }^{2}$ Green Safe Cities Research Group, Universiti Teknologi MARA, Shah Alam Campus,40450, Selangor, Malaysia. \\ ${ }^{3}$ Department of Architecture, Faculty of Architecture, Planning \& Surveying, Universiti Teknologi MARA Perak Branch, Seri Iskandar \\ Campus, 32610, Perak, Malaysia. \\ ${ }^{4}$ Faculty of Fine Arts, Helwan University Cairo - Zamalek, 4 Mohamed Thakeb. St Zamalek, Cairo, Egypt. \\ lindakeruing@gmail.com, sitir704@perak.uitm.edu.my,, ismai578@perak.uitm.edu.my, Heba.abdelhafeez@f-arts.helwan.edu.eg \\ Tel of $1^{\text {st }}$ Author: 0135185148
}

\begin{abstract}
Autism occurs in every racial and ethnic group gives a life-long impact to their affected relative. Conducive physical learning environment deliver benefit and helps autistic children improve their skill and performance. This research aims to develop a framework of the Physical Learning Environment and determine the respondent knowledge of awareness on physical learning environment for designing autism. In summary, there are nine components involved: building scale, accessibility, wayfinding, toilet provision, window, ventilation/heating, threshold, legibility, and furniture. The significance of this research could contribute to creating a quality environment for autistic children within the Malaysian context.
\end{abstract}

Keywords: Autism; physical learning environment; descriptive analysis.

eISSN: 2398-4287@ 2021. The Authors. Published for AMER ABRA cE-Bs by e-International Publishing House, Ltd., UK. This is an open access article under the CC BYNC-ND license (http://creativecommons.org/licenses/by-nc-nd/4.0/). Peer-review under responsibility of AMER (Association of Malaysian Environment-Behaviour Researchers), ABRA (Association of Behavioural Researchers on Asians/Africans/Arabians) and cE-Bs (Centre for Environment-Behaviour Studies), Faculty of Architecture, Planning \& Surveying, Universiti Teknologi MARA, Malaysia.

DOI: https://doi.org/10.21834/ebpj.v6i17.2803

\subsection{Introduction}

Autism Spectrum Disorder (ASD) is the broad term for a complex neurodevelopmental disability that impaired verbal and non-verbal communication and social interaction. The learning environment has become significant because research has proven that the quality of educational facilities affects learning outcomes toward the individuals within the building (Nazri \& Ismail, 2016). To enhance the development of children with autism, they stressed that it is crucial to ensure that the building is practical, convenient, fit and feasible for all children to use, especially for children with autism (C.S. Martin, 2014). Therefore, an architect's role and responsibility is to provide a design that responds to all society members, especially autistic. Architects need to understand the experience of those who are most sensitive to their surroundings. The built environment could be overwhelming, alienating, and challenging to negotiate.

The sensory and social difficulties characteristic of the disorder would provide the surrounding environment with increased significance as a source of stimulation and distraction. This issue can be a barrier to learning, hampering the child's development

eISSN: 2398-42870 2021. The Authors. Published for AMER ABRA cE-Bs by e-International Publishing House, Ltd., UK. This is an open access article under the CC BYNC-ND license (http://creativecommons.org/licenses/by-nc-nd/4.0/). Peer-review under responsibility of AMER (Association of Malaysian Environment-Behaviour Researchers), ABRA (Association of Behavioural Researchers on Asians/Africans/Arabians) and CE-Bs (Centre for Environment-Behaviour Studies), Faculty of Architecture, Planning \& Surveying, Universiti Teknologi MARA, Malaysia.

DOI: https://doi.org/10.21834/ebpj.v6i17.2803 
(Mcnally et al., 2013). However, designers lack awareness of sensory issues regarding the built environment in the daily life of autism before the designing stage. Any unwanted distraction can negatively impact that child's ability to learn (Mcnally et al., 2013; Fulton, Eapen, ÄCErnÄrec, Walter, \& Rogers, 2014; The National Autistic Society, 2015). Once autistic children starting their learning process, the quality of the environment is so much essential and avoid confusion and frustration to the autistic mind (Beaver, 2006). Autism is a highly complex condition that affects each person differently and can benefit more from the built environment's sensory input (The National Autistic Society, 2015). This research aims to develop a framework of the Physical Learning Environment, and this paper to determine the respondent's knowledge of awareness on physical learning environment for designing autism. Physical Learning Environment (PLE) is related to the environment that affects children's learning processes, supporting the well-being and education of children with ASD via the classroom. The significance of this research could contribute to creating a quality environment for autistic children within the Malaysian context.

\subsection{Literature Review}

The Learning environment and features play a major role in improving learning in schools. It can stimulate students to engage in the learning process, influence students' behaviour, and assist in developing their skills or cognitive perception. Research done by Shaari \& Ahmad (2016) proved a link between the physical learning environment and children's school readiness. Therefore, the physical learning environment can no longer ignore. They suggested that quality and adequately designed physical learning environment will boost the development and education of children and contribute to improved school readiness among children and a better education system. Thus, ensuring that school children are ready is essential when designing a school. There are nine components to be highlighted in the following section: building scale, accessibility, wayfinding, toilet provision, window, ventilation/heating, threshold, legibility, and furniture.

The first component is building scale, or those with simple building layouts offer the most basic surroundings for autistic. They would be most calm in an environment that they can easily comprehend. The large school can be a daunting, sometimes disorienting, universe for most children (Mcnally et al., 2013). Previous research showed that the accessibility should considered and improved, including steps, stairways, kerbs, exterior surfaces, paving, parking areas, building entrances and exits (including emergency escape routes). In addition, internal and external doors, gates, toilets and washing facilities, lighting, heating, ventilation, lifts, signs, interior surfaces, floor coverings, room décor and furniture (Kinnaer et al., 2016). Prior research highlighted that the circulation area could potentially distress pupils (Mcnally et al., 2013). Complex layouts, long corridors, and frequent level changes can contribute to a feeling of disorientation and create a sense of anxiety (Mcnally et al., 2013). An effort to provide wayfinding suggested ensuring the circulation around the school as clear and comprehensible as possible (Mcnally et al., 2013). Studies of physical learning environment are well documented; it is also well acknowledged that the toilet provision should consider the ergonomic that suits the children. Mcallister \& Maguire (2012) suggested that the classroom should have direct access to the toilets. Safety is essential when designing showers and bathrooms. Therefore pipes must not be exposed, toilet cisterns are boxed in or have lockable lids and fittings must be firmly fixed, or otherwise, the autistic could pull out of their place (Arnaiz et al., 2011; Mcnally et al., 2013).

Previous studies have emphasised that windows might be a safety problem, as Arnaiz et al. (2011) mentioned, and advised placing mechanisms to restrict their opening. They suggested the windows could be locked from the interior, and the glazing should be made of safety glass for both the exterior and the interior sides. The physical learning environment should promote healthy living through nontoxic materials, the availability of natural light, good ventilation and the incorporation of universal design strategies (Ahrentzen \& Steele, 2013). To supply plenty of fresh air such as effective cross-ventilation, high ceiling vents, aligned doors and windows (Moore \& Sugiyama, 2007). The literature review shows that threshold spaces are personalised spaces that allow children to adapt to the environmental and spatial change from one space to another (Scott, 2009). The exchange of physical activity can complicated for the autistic child, and the threshold is the point of exchange and transference between two different environments (Mcallister \& Maguire, 2012).

Meanwhile, legibility is a good environment's qualities to ease confusion among autistic (Mcnally et al., 2013). The learning environment would be more accessible if it provides visual clues that help the child orientate themselves and identify the activities associated with various rooms. Mcnally et al. (2013) suggested that using individual colours or objects can assist them in identifying a place with a specific activity (Mcnally et al., 2013). The final component is the classroom furniture, such as workstations, desks and shelving storage units, supported in increasing the legibility and understanding of the autistic (Mcallister \& Maguire, 2012). Knowing autistic children with unpredictable behaviour tend to harm themselves by scratching the walls, running around the furniture, and accidentally hitting the walls. Therefore, designers should understand the necessity of smoothly finished walls with variegated textures to differentiate between the materials (Manchala, 2014).

\subsection{Methodology}

This study is quantitative, using a questionnaire. The purposive sampling method was used and, the questionnaire survey asks the respondents about their knowledge of awareness regarding the autism environment.

\subsection{Participants}

The study's sampling includes respondents involved in the autism learning environment. They should give opinions on the autism learning environment, and the respondent may or may not experience designing or creating the autism learning environment.

Three hundred eighty-four (384) respondents participated in this survey. However, one hundred seventy-four (174) questionnaires were successfully collected. 


\subsection{Questionnaire Survey}

The instrument measures based on a five-point Likert scale, ranging from one (1) - (Strongly Disagree) to five (5) - (Strongly Agree). The questionnaire is divided into seven sections; Section 1 - Information sheet, Section 2 - Instruction for rating measure, Section 3 Demographic information, Section 4 - Sensory Sensitivity (sight, sound, smell, taste, touch, proprioception and Vestibular), Section 5 Sensory Stimulation (acoustic, colour, smell, lighting and visual), Section 6 - Sensory Design (acoustic, spatial sequencing, escape space, compartmentation, transition zone, sensory zoning, safety and security), and Section 7 - Physical Learning Environment (building scale, accessibility, wayfinding, toilet provision, window, ventilation/heating, threshold, legibility and furniture).

\subsection{Response Rate}

According to Solans-Domènech et al. (2019), the response rates for postal surveys are low. The researchers initially contacted the secretariat, known as key persons, to seek permission to conduct the study to maximise the response rate. Solans-Domènech et al. (2019) suggested that although the response rate was lower than expected, $43 \%$ is within the normal range for online surveys. The calculation for response rate is the number of returned questionnaires divided by the number of distributed questionnaires (the sample). The figure is multiplying by 100 to express a percentage figure. Hence, out of 384 distributed questionnaires, 174 questionnaires were returned. Therefore, a $45.3 \%$ response rate was registered for this survey.

\subsection{Limitation}

During data collection, there is a limitation where the pandemic covid-19 and Movement Control Order (MCO) accrued in Malaysia. Thus, the researcher used email and online to conduct the survey. However, some respondents are more interested in meeting with researchers while responding to the questionnaire.

\subsection{Data Analysis}

This analysis attempts to achieve the objective, which is to determine the respondent knowledge of awareness on physical learning environment for designing autism. Descriptive statistic used to examine the data collection. This study's outcome generally shows average value, minimum ( $\mathrm{min}$ ) value, maximum (max) value, mean and standard deviation from descriptive statistics for PLE. This paper highlights the result for the mean of Physical Learning Environment (PLE). Besides, descriptive analysis was deemed adequate to explain the variables' characteristics and conclude the numerical data.

\subsection{Findings}

This section highlights the Physical Learning Environment (PLE) result and determines the respondent knowledge of awareness on the physical learning environment for designing for autism. This variable has nine components: the result analysis for building scale, accessibility, wayfinding, toilet provision, window, ventilation/heating, threshold, legibility, and furniture. Overall, most respondents strongly agreed and agreed regarding the components with the highest score mean is furniture. Table 1 showed the result of descriptive analysis for nine components of the Physical Learning Environment (PLE).

Table 1. Descriptive statistic of the Physical Learning Environment (PLE)

\begin{tabular}{|c|c|c|c|c|c|}
\hline Dimension & Code & Item & $\mathbf{N}$ & Mean & St. Deviation \\
\hline \multirow[t]{5}{*}{ Building Scale } & PLE1 & $\begin{array}{l}\text { Small-scale schools offer the most } \\
\text { basic environment. }\end{array}$ & 174 & 3.99 & 0.887 \\
\hline & PLE2 & $\begin{array}{l}\text { Simple building designs make it } \\
\text { easier to get around on their own. }\end{array}$ & 174 & 4.26 & 0.809 \\
\hline & PLE3 & $\begin{array}{l}\text { Staircases can be daunting for } \\
\text { autistic. }\end{array}$ & 174 & 3.79 & 0.920 \\
\hline & PLE4 & $\begin{array}{l}\text { Long corridors can be frightening for } \\
\text { autistic children. }\end{array}$ & 174 & 3.82 & 0.925 \\
\hline & PLE5 & $\begin{array}{l}\text { The variety of classrooms can } \\
\text { confuse for autistic. }\end{array}$ & 174 & 3.82 & 0.911 \\
\hline \multirow[t]{5}{*}{ Accessibility } & PLE6 & $\begin{array}{l}\text { Difficulties adapting to the 'hustle' of } \\
\text { school environment. }\end{array}$ & 174 & 4.07 & 0.847 \\
\hline & PLE7 & Stress-free school environment & 174 & 4.26 & 0.831 \\
\hline & PLE8 & $\begin{array}{l}\text { The school surrounding must be } \\
\text { clear to make it more accessible. }\end{array}$ & 174 & 4.06 & 0.898 \\
\hline & PLE9 & $\begin{array}{l}\text { Arrival at the school is a critical } \\
\text { moment for autistic. }\end{array}$ & 174 & 4.03 & 0.879 \\
\hline & PLE10 & $\begin{array}{l}\text { During arrival at the school the } \\
\text { autistic should go to the entrance. }\end{array}$ & 174 & 3.97 & 0.863 \\
\hline Wayfinding & PLE11 & $\begin{array}{l}\text { Circulation areas may potentially } \\
\text { distress for autistic children. }\end{array}$ & 174 & 4.24 & 0.844 \\
\hline
\end{tabular}




\begin{tabular}{|c|c|c|c|c|c|}
\hline & PLE12 & $\begin{array}{l}\text { Complex layouts can contribute to a } \\
\text { feeling of disorientation. }\end{array}$ & 174 & 3.93 & 0.953 \\
\hline & PLE13 & $\begin{array}{l}\text { Long corridors can create a sense of } \\
\text { anxiety for autistic children. }\end{array}$ & 174 & 3.94 & 0.854 \\
\hline & PLE14 & $\begin{array}{l}\text { Frequent changes of level can create } \\
\text { a sense of anxiety }\end{array}$ & 174 & 4.20 & 0.833 \\
\hline & PLE15 & $\begin{array}{l}\text { Circulation must be clear with } \\
\text { understandable as possible. }\end{array}$ & 174 & 4.36 & 0.804 \\
\hline \multirow[t]{5}{*}{ Toilet Provision } & PLE16 & $\begin{array}{l}\text { The toilet fittings should be } \\
\text { ergonomic suitable for children. }\end{array}$ & 174 & 4.02 & 0.873 \\
\hline & PLE17 & $\begin{array}{l}\text { The toilet should have direct access } \\
\text { from the autistic classroom. }\end{array}$ & 174 & 4.10 & 0.831 \\
\hline & PLE18 & $\begin{array}{l}\text { The toilet cisterns should conceal } \\
\text { adequately. }\end{array}$ & 174 & 3.79 & 0.862 \\
\hline & PLE19 & $\begin{array}{l}\text { The hand drier sounds lead to } \\
\text { anxiety among autistic children }\end{array}$ & 174 & 3.52 & 0.845 \\
\hline & PLE20 & $\begin{array}{l}\text { The flush of wc noise contributes } \\
\text { stress to autistic children. }\end{array}$ & 174 & 4.01 & 0.819 \\
\hline \multirow[t]{4}{*}{ Window } & PLE21 & $\begin{array}{l}\text { Curtains or blinds prevent visual } \\
\text { distractions from outside. }\end{array}$ & 174 & 4.12 & 0.792 \\
\hline & PLE22 & $\begin{array}{l}\text { Openable window should be fitted } \\
\text { with a device to limit opening. }\end{array}$ & 174 & 3.84 & 0.923 \\
\hline & PLE23 & $\begin{array}{l}\text { Visual distraction can be an issue if a } \\
\text { large window introduced. }\end{array}$ & 174 & 3.69 & 0.977 \\
\hline & PLE24 & $\begin{array}{l}\text { Or provides windows at a high level } \\
\text { in the classroom. }\end{array}$ & 174 & 3.78 & 0.996 \\
\hline \multirow[t]{5}{*}{ Ventilation/heating } & PLE25 & $\begin{array}{l}\text { An architect should design the } \\
\text { classroom with natural ventilation. }\end{array}$ & 174 & 3.99 & 0.822 \\
\hline & PLE26 & $\begin{array}{l}\text { The cooling system should be } \\
\text { controlled separately. }\end{array}$ & 174 & 4.13 & 0.780 \\
\hline & PLE27 & $\begin{array}{l}\text { Care should be taken to reduce } \\
\text { related noises from the systems. }\end{array}$ & 174 & 3.64 & 0.874 \\
\hline & PLE28 & $\begin{array}{l}\text { The autistics are sensitive to the cold } \\
\text { due to their sensory is disrupted. }\end{array}$ & 174 & 3.71 & 0.819 \\
\hline & PLE29 & $\begin{array}{l}\text { The autistics are sensitive to the hot } \\
\text { due to their sensory is disrupted. }\end{array}$ & 174 & 3.93 & 0.823 \\
\hline \multirow[t]{5}{*}{ Threshold } & PLE30 & $\begin{array}{l}\text { Space to allow the autistic children to } \\
\text { adapt quickly to the environment. }\end{array}$ & 174 & 4.03 & 0.800 \\
\hline & PLE31 & $\begin{array}{l}\text { The transition for autistic children } \\
\text { should be made more accessible. }\end{array}$ & 174 & 3.84 & 0.808 \\
\hline & PLE32 & $\begin{array}{l}\text { To considers the transition from the } \\
\text { exterior into the classroom. }\end{array}$ & 174 & 4.17 & 0.808 \\
\hline & PLE33 & $\begin{array}{l}\text { Provision for a cloakroom for the } \\
\text { autistic to enter the classroom. }\end{array}$ & 174 & 4.09 & 0.839 \\
\hline & PLE34 & $\begin{array}{l}\text { Where the autistic can ready them } \\
\text { for entry out into the wider area. }\end{array}$ & 174 & 4.07 & 0.826 \\
\hline \multirow[t]{5}{*}{ Legibility } & PLE35 & $\begin{array}{l}\text { Using special colour coding in } \\
\text { identifying a specific place. }\end{array}$ & 174 & 4.05 & 0.832 \\
\hline & PLE36 & $\begin{array}{l}\text { Using individual objects in identifying } \\
\text { the music room. }\end{array}$ & 174 & 3.84 & 0.934 \\
\hline & PLE37 & $\begin{array}{l}\text { Providing visual clues that help the } \\
\text { autistic to orientate themselves. }\end{array}$ & 174 & 3.61 & 0.941 \\
\hline & PLE38 & $\begin{array}{l}\text { Providing visual clues that help the } \\
\text { child to identify the activities. }\end{array}$ & 174 & 4.40 & 0.803 \\
\hline & PLE39 & $\begin{array}{l}\text { Classrooms where multiple activities } \\
\text { can be confusing for autistic. }\end{array}$ & 174 & 4.23 & 0.870 \\
\hline \multirow[t]{2}{*}{ Furniture } & PLE40 & $\begin{array}{l}\text { The natural colour from wood } \\
\text { finishes is suitable for autistic. }\end{array}$ & 174 & 4.29 & 0.796 \\
\hline & PLE41 & $\begin{array}{l}\text { The designer should select non-toxic } \\
\text { or chemical-free furniture. }\end{array}$ & 174 & 4.27 & 0.920 \\
\hline
\end{tabular}




\begin{tabular}{cll|c|c|c} 
PLE42 & $\begin{array}{l}\text { The designer should consider the } \\
\text { smooth finished materials. }\end{array}$ & 174 & 4.23 & 0.870 \\
PLE43 & $\begin{array}{l}\text { Rubber balls at furniture legs to } \\
\text { prevent scratching sounds. } \\
\text { Designers should consider furniture } \\
\text { with curved edges to walls. }\end{array}$ & 174 & 4.27 & 0.920 \\
PLE44 & (Source: Authors)
\end{tabular}

\subsection{Discussion}

Most respondents are strongly agreed and their knowledge of awareness toward building scale. The results demonstrated in this section match the previous studies showing that small-scale schools offer the most basic surroundings for easy understanding (Ghazali et al., 2018a). Hence, to avoid anxiety to autistic, Leestma (2015) suggested that corridors should be designed as simple spaces and for play or rest. This approach appropriates the space for the student's needs. The following result for accessibility showed that most respondents strongly agreed as autistic children should be provided with a stress-free school environment. This result ties nicely and supported previous studies that designers could enhance the effectiveness by ensuring accessibility and employing universal design for learning on disability issues (Stack, 2006). Likewise, Tuckett et al. (2004) advised taking whatever steps can be reasonably expected to ensure that their buildings are made fully accessible. The case of wayfinding indicated that most respondents are strongly agreed. This is consistent with what has been found in previous studies that they could not differentiate typical visual cues such as exit or restroom signage. Hence, careful attention to wayfinding and places of transition for the successful use of environments (Paron-Wildes, 2005). In addition, wayfinding expected to support autistic to avoid confusion and distress when losing their spatial orientation (Altenmüller-Lewis, 2017).

In terms of toilet provision, the respondents' result ties well with previous studies that the toilet should have direct physically accessible for all children from the classroom (Mcallister \& Maguire, 2012; Haddad, 2015). In addition, the toilet area should include adequate space for changing, fixtures and fittings should be at children ergonomic (Mcallister \& Maguire, 2012; Block, 2018). In the case of the window, most respondents strongly agreed that their knowledge of awareness was in line with previous studies that considered avoiding distractions with limited doors and window locations (Caren S. Martin, 2014). Furthermore, it provides high-level windows to the exterior considering the building orientation, glare and possible solar gain (Block, 2018). The respondent agreement also shows that their knowledge of awareness supports previous studies that become a safety concern. The window should be locks or mechanisms that will prevent its opening (Leestma, 2015). The next component is ventilation/heating; most respondents strongly agreed that their awareness is in line, as discussed by previous scholars, that ventilation/heating is a significant source of background noise in learning environments. Altering this sensory input and providing options for using temperature control systems helps to accommodate specific autistic needs. The outcome showed behaviour might be improved, or at least a more conducive environment created more efficient skill development and improved performance (Mostafa, 2014) (Gopal \& Raghavan, 2018).

In terms of threshold, most respondents strongly agreed to consider the design. The respondent shows that their knowledge of awareness in line, as discussed by previous scholars, is essential for them to give time, space to prepare for the change and helps with anxieties surrounding sudden sensory change (Ghazali et al., 2019; Love, 2019). This is important because, without the transition space, the shock of going from low stimulus to high stimulus could impact children's performance (Leestma, 2015). The following component is legibility, and most respondents strongly agreed. Their agreement shows that their knowledge of awareness is in line as discussed by the previous scholar that legibility is a good environment helps to ease of understanding and would be more accessible to autistic children to orientate themselves and identify the activities associated with various rooms (Mcnally et al., 2013; Oi-Zhen et al., 2015; Ghazali, Md Sakip, et al., 2019). The final component for Physical Learning Environment is furniture. The majority of respondents strongly agreed, as in line with previous studies, that furniture and finishes positively impacted users (Shepley et al., 2013). Likewise, designed furniture should be ergonomic and standard classroom furniture and comfortable for the autistic (Haddad, 2015). While robustness, furniture and any other fixtures throughout the building should designed to be safe and secure (Ismail \& Nazri, 2016; Arnaiz et al., 2011; Stuart, n.d.; Magda Mostafa, 2015a).

\subsection{Conclusions and Recommendations}

This paper indicates that the physical learning environment is the essential feature attributes to a conducive learning environment. The analysis shows that the respondent strongly agrees with all elements in the physical learning environment. Nevertheless, the highest score with $56.3 \%$ (strongly agree) for legibility provides visual clues that help the child identify the activities. Whereas the lowest is toilet provision with a score $48.9 \%$ (not sure) for the hand drier sounds lead to anxiety among autistic children. The result analysis yielded that the respondent's awareness strongly agreed that the components are the essentials to be considered in the design for autism. Future studies in developing the framework using the SEM-PLS software by measurement model analysis \& structural model analysis would further devote. Perhaps, the framework demonstrated a new contribution to knowledge concerning designing for an autistic environment. 


\section{Acknowledgement}

I would like to thank my supervisor Dr Siti Rasidah Md Sakip, and Asso. Prof. Dr Ismail Samsuddin for supporting me. Also, I would thank Jabatan Kerja Raya Malaysia for allowing me to further my study.

\section{Paper Contribution to Related Field of Study}

Through this study's findings, the paper pointed out that legibility would enhance a better physical learning environment for autistic. Legibility is one of the components to be highlighted during the design stage. Ultimately, it helps autistic more understand the environment with high satisfaction levels among autistic children that would benefit and reduce stress and anxiety on them.

\section{References}

Ahrentzen, S., \& Steele, K. (2013). Autism and Design.

Altenmüller-Lewis, U. (2017). Designing Schools for Students on the Spectrum. The Design Journal, 20(sup1), S2215-S2229. https://doi.org/10.1080/14606925.2017.1352738

Arnaiz, P., Segado, F., \& Albaladejo, L. (2011). Autism and the Built Environment. Autism Spectrum Disorders - From Genes to Environment, 363-380. https://doi.org/10.5772/20200

Beaver, C. (2006). Designing Environments for Children \& Adults with ASD. In Autism Safari 2006 2nd World Autism Congress \& Exhibition.

Block, S. M. (2018). Classroom Design and its Influence on Students 'Performance Within the Autism Spectrum Diagnosis. St. Cloud State University.

Fulton, E., Eapen, V., ÄCErnÄlec, R., Walter, A., \& Rogers, S. (2014). Reducing Maladaptive Behaviors in Preschool-Aged Children with Autism Spectrum Disorder Using the Early Start Denver Model. Frontiers in Pediatrics, 2(May), 1-10. https://doi.org/10.3389/fped.2014.00040

Ghazali, R., Md Sakip, S. R., \& Samsuddin, I. (2018). A Review of Sensory Design Physical Learning Environment for Autism Centre. E-IPH, AicQoL2018Perhentianlsland, 3(7), 7 pages.

Ghazali, R., Md Sakip, S. R., \& Samsuddin, I. (2019). Creating Positive Environment for Autism Using Sensory Design. Environment-Behaviour Proceedings Journal 4(10), 19. https://doi.org/10.21834/e-bpj.v4i10.1618

Gopal, A., \& Raghavan, J. (2018). Design interventions for Sensory comfort of Autistic children. Autism-Open Access, 08(01), 1-8. https://doi.org/10.4172/21657890.1000227

Haddad, C. (2015). Teaching Children with Disabilities in Inclusive Settings. In The United Nations Educational, Scientific and Cultural Organization \& UNESCO Bangkok. UNESCO Bangkok Office Asia and Pacific Regional Bureau for Education.

Ismail, Z., \& Nazri, N. A. (2016). A Framework for Educational Building Facilities for Children with Autism in. International Journal of Humanities and Cultural Studies, 3(1), 2158-2176.

Kinnaer, M., Baumers, S., \& Heylighen, A. (2016). Autism-friendly architecture from the outside in and the inside out: an explorative study based on autobiographies of autistic people. Journal of Housing and the Built Environment, 31(2), 179-195. https://doi.org/10.1007/s10901-015-9451-8

Leestma, D. P. (2015). Designing for the Spectrum: An Educational Model for the Autistic User. College Park.

Love, J. S. (2019). Studio teaching experiments - Spatial transitioning for autism schools. Archnet-IJAR, 13(1), 39-57. https://doi.org/10.1108/ARCH-11-2018-0019

Manchala, S. (2014). Center for Autistic Children: An Architectural Intervention (Issue November). Vijayawada.

Martin, C.S. (2014). Exploring the impact of the design of the physical classroom environment on young children with autism spectrum disorder (ASD). Journal of Research in Special Educational Needs, 16(4), 19 pages. https://doi.org/10.1111/1471-3802.12092

Martin, Caren S. (2014). Exploring the impact of the design of the physical classroom environment on young children with autism spectrum disorder (ASD). Journal of Research in Special Educational Needs, 16(4), 280-298. https://doi.org/10.1111/1471-3802.12092

Mcallister, K., \& Maguire, B. (2012). Design considerations for the autism spectrum disorder-friendly Key Stage 1 classroom. British Journal of Learning Support Support for Learning, 27(3), 103-112. https://doi.org/10.1111/j.1467-9604.2012.01525.x

Mcnally, H., Morris, D., \& Mcallister, K. (2013). Experiencing Primary School through the lens of the autistic spectrum. Aldo goes to Primary School (D. M. \& K. M. A. Hugh McNally (ed.)). McNally Morris Architects.

Moore, G. T., \& Sugiyama, T. (2007). The Children's Physical Environment Rating Scale (CPERS): Reliability and Validity for Assessing the Physical Environment of Early Childhood Educational Facilities. Children, Youth and Environments, 17(4), 24-53. https://doi.org/10.7721/chilyoutenvi.17.4.0024

Mostafa, M. (2014). Architecture For Autism: Autism ASPECTSS?? in School Design. International Journal of Architectural Research-Archnet-IJAR, 8(1), 143-158.

Mostafa, M. (2015). An Architecture for Autism: Built Environment Performance in Accordance to the Autism ASPECTSSTM Design Index. Design Principles and Practices: An International Journal-Annual Review, 8(1), 55-71. https://doi.org/10.18848/1833-1874/cgp/v08/38300 
Nazri, N. A., \& Ismail, Z. (2016). Educational building facilities for children with autism in Malaysia. Jurnal Teknologi. https://doi.org/10.11113/jt.v78.8489

Oi-Zhen, S., Weng-Wai, C., \& Yu-Tian, T. (2015). Quality of healing environment in healthcare facilities. Jurnal Teknologi, 74(2), 101-108. https://doi.org/10.11113/jt.v74.4529

Paron-Wildes, A. J. (2005). Sensory Stimulation and Autistic Children. Implications, 06(04), 1-5.

Parsian, N., Ghorashi, Z., yousefy, A., \& merghati-khoei, E. (2016). Developing and validating a questionnaire to measure women's sexual behaviors: A psychometric process. Galen Medical Journal, 1(1), 208-214.

Scott, I. (2009). Designing learning spaces for children on the autism spectrum. Good Autism Practices, (10)1(1), 36-51.

http://www.research.ed.ac.uk/portal/en/publications/designing-learning-spaces-for-children-on-the-autism-spectrum(5e79c41d-b247-4eae-8474-db297b91d05f).html

Shaari, M. F., \& Ahmad, S. S. (2016). Physical Learning Environment: Impact on Children School Readiness in Malaysian Preschools. Procedia - Social and Behavioral Sciences, 222, 9-18. https://doi.org/10.1016/j.sbspro.2016.05.164

Shepley, M. M., Pasha, S., Ferguson, P., Oproescu, G., Huffcut, J. C., Young, J., Kiyokawa, G., Zadeh, R. S., Martere, J., Zborowsky, T., Meyerhoeffer, T., Zimring, C., \& Mcdermott, B. (2013). Design Research And Behavioral Health Facilities. 81. https://www.healthdesign.org/sites/all/modules/civicrm/extern/url.php?u=77927\&qid=

Solans-Domènech, M., MV Pons, J., Adam, P., Grau, J., \& Aymerich, M. (2019). Development and validation of a questionnaire to measure research impact. Research Evaluation, 28(3), 253-262. https://doi.org/10.1093/reseval/rvz007

Stack, E. (2006). An Evaluation of Educational Provision for Children with autistic Spectrum Disorders.

Stuart, S. (n.d.). Why Buildings for Autistic People Are Better for Everyone.

The National Autistic Society. (2015). Autism-friendly Design. Your Autism Magazine, 49(2), 3 pages. http://www.autism.org.uk/professionals/others/architects/autismfriendly-design.aspx

Tuckett, P., Marchant, R., \& Jones, M. (2004). Cognitive impairment, access and the built environment. March.

Yong, A. G., \& Pearce, S. (2013). A Beginner's Guide to Factor Analysis: Focusing on Exploratory Factor Analysis. Tutorials in Quantitative Methods for Psychology 9(2), 79-94. https://doi.org/10.20982/tqmp.09.2.p079 